\title{
ASSOCIATION OF SPINOPELVIC PARAMETERS WITH THE LOCATION OF LUMBAR DISC HERNIATION
}

\author{
ASSOCIAÇÃO DOS PARÂMETROS ESPINOPÉLVICOS COM A LOCALIZAÇÃO \\ DA HÉRNIA DISCAL LOMBAR
}

\section{ASOCIACIÓN DE PARÁMETROS ESPINOPÉLVICOS CON LA UBICACIÓN DE HERNIA DE DISCO LUMBAR}

Jefferson Coelho de Léo ${ }^{1}$, Álvaro Coelho de Léo ${ }^{2}$, Igor Machado Cardoso ${ }^{1}$, Charbel Jacob Júnior ${ }^{1}$, José Lucas Batista Júnior ${ }^{1}$

\begin{abstract}
Objective: To associate spinopelvic parameters, pelvic incidence, sacral slope, pelvic tilt and lumbar lordosis with the axial location of lumbar disc herniation. Methods: Retrospective study, which evaluated imaging and medical records of 61 patients with lumbar disc herniation, who underwent surgery with decompression and instrumented lumbar fusion in only one level. Pelvic incidence, sacral slope, pelvic tilt and lumbar lordosis with simple lumbopelvic lateral radiographs, which included the lumbar spine, the sacrum and the proximal femur. The affected segment was identified as the level and location of lumbar disc herniation in the axial plane with MRI scans. Results: Of 61 patients, 29 (47.5\%) had low lumbar lordosis; in this group 24 (82.8\%) had central disc herniation, 4 (13.8\%) had lateral recess disc herniation and $1(3.4 \%)$ had extraforaminal disc herniation $(p<0.05)$. Of the 61 patients, 18 (29.5\%) had low sacral slope; of this group $15(83.3 \%)$ had central disc herniation and $3(16.7 \%)$ had disc herniation in lateral recess $(p<0.05)$. Conclusions: There is a trend towards greater load distribution in the anterior region of the spine when the spine has hypolordotic curve. This study found an association between low lordosis and central disc herniation, as well as low sacral slope and central disc herniation.
\end{abstract}

Keywords: Spinal diseases; Intervertebral disc displacement; Pelvis; Lordosis; Intervertebral disc degeneration.

\section{RESUMO}

Objetivo: Associar os parâmetros espinopélvicos, incidência pélvica, inclinação sacral, versão pélvica e lordose lombar com a localização axial da hérnia discal lombar. Métodos: Estudo retrospectivo, em que foram avaliados exames de imagem e prontuários de 61 pacientes portadores de hérnia discal lombar submetidos a tratamento cirúrgico com descompressão e artrodese lombar instrumentada em apenas um nível. Foram aferidos incidência pélvica, declive sacral, versão pélvica e lordose lombar nas radiografias lombopélvicas simples em perfil, que incluíram a coluna lombar, o sacro e o terço proximal do fêmur. O segmento acometido foi identificado quanto ao nível e à localização da hérnia discal lombar no plano axial com exames de ressonância magnética. Resultados: Dos 61 pacientes, 29 (47,5\%) apresentaram lordose lombar baixa; deste grupo 24 (82,8\%) tinham hérnia central, 4 (13,8\%), hérnia em recesso e 1 (3,4\%), hérnia extraforaminal ( $p<0,05)$. Dos 61 pacientes, 18 (29,5\%) apresentaram declive sacral baixo; deste grupo, 15 (83,3\%) apresentaram hérnia central e $3(16,7 \%)$, hérnia em recesso $(p<0,05)$. Conclusões: Existe uma tendência de maior distribuição de cargas na região anterior da coluna quando a coluna é hipolordótica. Este estudo observou uma associação entre lordose baixa e hérnia discal central, assim como declive sacral baixo e hérnia central.

Descritores: Doenças da coluna vertebral; Deslocamento do disco intervertebral; Pelve; Lordose; Degeneração do disco intervertebral.

\section{RESUMEN}

Objetivo: Asociar parámetros espinopélvicos, incidencia pélvica, pendiente sacra, versión de la pelvis y lordosis lumbar con la ubicación axial de hernia de disco lumbar. Métodos: Estudio retrospectivo que evaluó imágenes y registros médicos de 61 pacientes con hernia de disco lumbar sometidos a una cirugía de descompresión y artrodesis lumbar instrumentada en un solo nivel. Se midieron la incidencia de la pelvis, la pendiente sacra, la versión de la pelvis y la lordosis lumbar con radiografías lumbopélvicas simples en perfil, que incluyeron la columna lumbar, el sacro y el fémur proximal. El segmento afectado fue identificado como el nivel y la localización de la hernia discal lumbar en el plano axial con imágenes de resonancia magnética. Resultados: De 61 pacientes, 29 (47,5\%) tenían lordosis lumbar baja; de este grupo 24 (82,8\%) tenían hernia central, 4 (13,8\%) tenían hernia en receso y 1 (3,4\%) tenía hernia extraforaminal (p < 0,05). De los 61 pacientes, 18 (29,5\%) tenían pendiente sacra baja; de este grupo 15 (83,3\%) tenían hernia central y 3 (16,7\%) hernia en receso $(P<0,05)$. Conclusiones: Existe una tendencia hacia una mayor distribución de la carga en la región anterior de la columna cuando la columna es hipolordótica. Este estudio encontró una asociación entre la baja lordosis y hernia de disco central, así como una baja pendiente sacra y la hernia central.

Descriptores: Enfermedades de la columna vertebral; Desplazamiento del disco intervertebral; Pelvis; Lordosis; Degeneración del disco intervertebral. 


\section{INTRODUCTION}

Disc herniation is defined as a continuous process of disc degeneration that causes the nucleus pulposus to migrate beyond the physiological limits of the annulus fibrosus. ${ }^{1}$ Lumbar disc herniations are more frequent in the fourth and fifth decades of life, with prevalence of $4.8 \%$ in men and of $2.5 \%$ in women over the age of 35 . The disease is considered a world health problem due to its epidemiological importance, and the physical and functional incapacity that it can produce. ${ }^{1-5}$

Its etiology is multifactorial, caused by the association of degenerative changes of the disc, which entail a reduction in the content of proteoglycans in the nucleus pulposus, with situations in which there is increased disc pressure, particularly in spinal flexion and rotation. ${ }^{1,2}$

Spinal alignment was, for many years, assessed only in the coronal plane, but several publications have highlighted the importance of changes in the sagittal plane. The analysis of sagittal balance appeared recently, and has been being correlated with the presence of herniated disc, degenerative disc disease, and spondylolisthesis. ${ }^{6-13}$

For the body balance in the sagittal axis, the pelvis and the spine are stabilizing factors between the head and the lower limbs. The alteration of these segments can change the behavior of adjacent segments in maintaining sagittal balance, leading to early degenerative changes, and greater energy expenditure. ${ }^{6-13}$

The main radiological parameters used to evaluate spinopelvic balance are pelvic incidence (PI), sacral slope (SS), pelvic tilt (PT) and lumbar lordosis (LL). Pelvic incidence is an individual anatomical constant that does not vary according to the posture adopted. PI corresponds to the result of the sum of the sacral slope and pelvic tilt angles. ${ }^{6-13}$ (Figure 1)

Roussouly et al. ${ }^{15}$ studied and classified lumbar lordosis in morphological patterns, and the corresponding degenerative progress of each curve, using pelvic incidence and sacral slope angle as reference. Patients with a low sacral slope $\left(<35^{\circ}\right)$ and slight pelvic tilt $\left(<45^{\circ}\right)$ have a tendency to present with early disc degeneration, central disc herniation or disc degeneration at multiple levels, due to the anterior displacement of forces. ${ }^{7,8,11,15}$

This study aims to associate the spinopelvic parameters pelvic incidence, sacral slope, pelvic tilt and lumbar lordosis with the axial location of the lumbar disc herniation.



Figure 1. Illustration - Spinopelvic balance. (A) Pelvic incidence. (B) Pelvic tilt. (C) Sacral slope.

\section{METHOD}

A retrospective study, approved by the Institutional Review Board, in which imaging scans and medical records of 61 patients of the department were evaluated ( $\left.N^{\circ} 35229314.4 .0000 .5065\right)$.

The inclusion criteria were patients with lumbar disc herniation who had undergone conservative treatment, with at least 20 physiotherapy sessions without improvement, patients who had undergone surgical treatment, or lumbar arthrodesis instrumented at only one level.

Patients without indication of surgical treatment, those who improved following physiotherapy, patients with previous lumbosacral surgery and those who had undergone surgical treatment at more than one level, as well as patients with other non-degenerative pathologies, were excluded from the study.

The spinopelvic balance was evaluated by measuring the angles of pelvic incidence, sacral slope, pelvic tilt and lumbar lordosis in the plain lumbopelvic radiographies with lateral views, which had to include the lumbar spine, the sacrum and the proximal third of the femur.

The angles in the radiographies were measured manually. Pelvic incidence $(\mathrm{PI})$ was obtained by the angle formed, in the lateralview radiography, by the line perpendicular to the sacral plateau, which originates from its midpoint, and by the line that runs from the center of the sacral plateau to the midpoint of the segment that joins the two centers of the femur heads, known as the biocoxofemoral axis. Pelvic tilt (PT) is composed of the intersection of a vertical line, perpendicular to the ground, with the line that joins the bicoxofemoral axis to the center of the sacral plateau. Sacral slope (SS) consists of the intersection of a horizontal line that follows the ground, with the line that accompanies the sacral plateau. (Figure 1) The upper edge of $L 2$ and the upper edge of S1 were used as a reference to measure lumbar lordosis. The sum of pelvic tilt and sacral slope angles is known to be equal to the value of pelvic incidence. $^{5-16}$ (Figure 2)

The angle measurements were compared with the normal values for the adult population, which have already been determined by

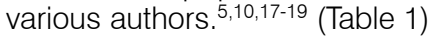

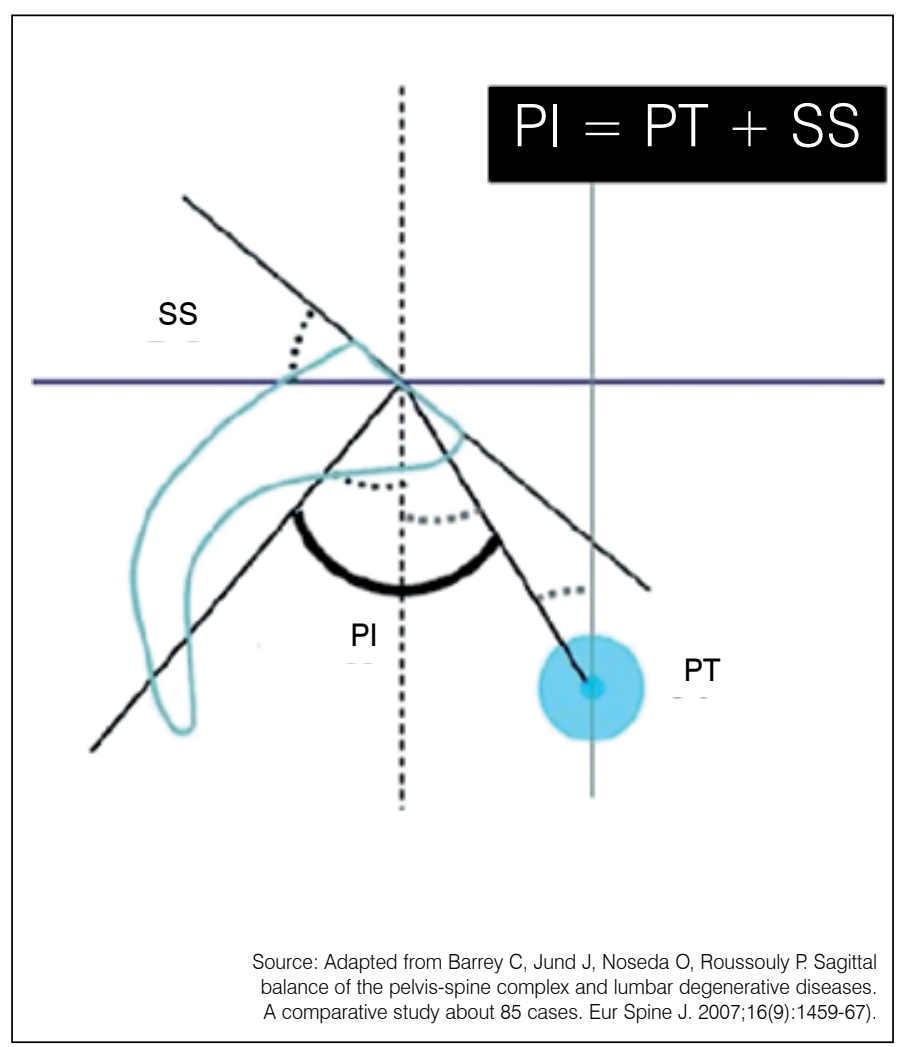

Figure 2. Pelvic incidence corresponds to the sum of the values of pelvic tilt and sacral slope. 
Table 1. Normal values of the spinopelvic ratio.

\begin{tabular}{c|c}
\hline Parameters & Degrees $\left(^{\circ}\right)$ \\
\hline Pelvic incidence (PI) & $40-65^{\circ}$ \\
\hline Pelvic tilt (PT) & $10-25^{\circ}$ \\
\hline Sacral slope (SS) & $30-50^{\circ}$ \\
\hline Lumbar lordosis & $40-80^{\circ}$ \\
\hline
\end{tabular}

The affected segment was identified with regards to the level and location of the herniated lumbar disc in the axial plane, according to the nomenclature of the Committee of the North American Spine Society (North American Spine Society, American Society of Spine Radiology and American Society of Neuroradiology) (Figure 3$)^{20}$ with Magnetic Resonance Imaging (MRI) scans. The MRI scans of the patients' lumbosacral spines were assessed at T1 and T2 in the axial and sagittal sequences, by a single observer.

Frequencies were analyzed with a confidence interval of $95 \%$ (95\% Cl - Taylor Series). The results were represented numerically via absolute values, and some data were also expressed as percentages. The Kolmogorov-Smirnov test was applied to determine whether the distribution of probability of the data is normal, and this hypothesis was accepted. The Student's t-test was applied for comparisons between the means of the variables. The data analysis was performed using Microsoft Office/Excel 2007 software.

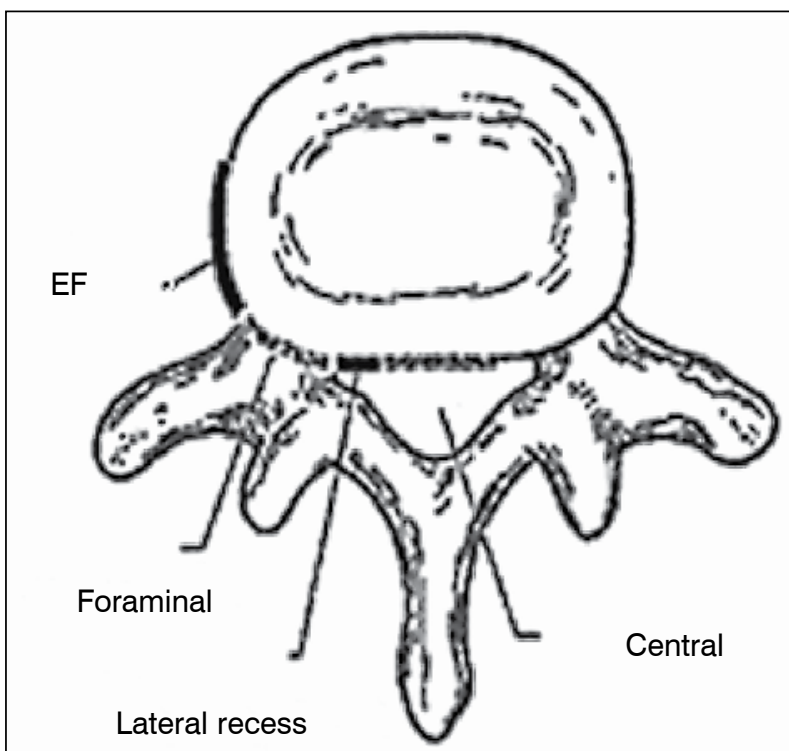

Source: Adapted from Fardon DF, Milette PC. Nomenclature and classification of lumbar disc pathology. Spine (Phila Pa 1976. 2001;26(5):E93-E113.

Figure 3. Nomenclature of the axial location of herniated lumbar discs.

\section{RESULTS}

A total of 61 patients were studied, 36 (59.00\%) of whom were male and 25 (41.00\%) female.

Of the 61 patients, 31 (50.81\%) presented with central disc herniation; 22 (38.89\%) with recess herniation; 4 with foraminal herniation (6.65\%); and 4 (6.65\%) with extraforaminal herniation (Figure 4$)$.

Of the 61 patients, 29 (47.5\%) presented with low lumbar lordosis, 26 (42.6\%) with normal lumbar lordosis, and six (9.8\%) with high lumbar lordosis.

Of the 29 patients with low lumbar lordosis, 24 (82.8\%) presented with central herniation; four (13.8\%) with recess herniation; $1(3.4 \%)$ presented with extraforaminal herniation. The Chi-square test indicates the presence of significant difference $(p<0.05)$. (Table 2 and Figure 5).

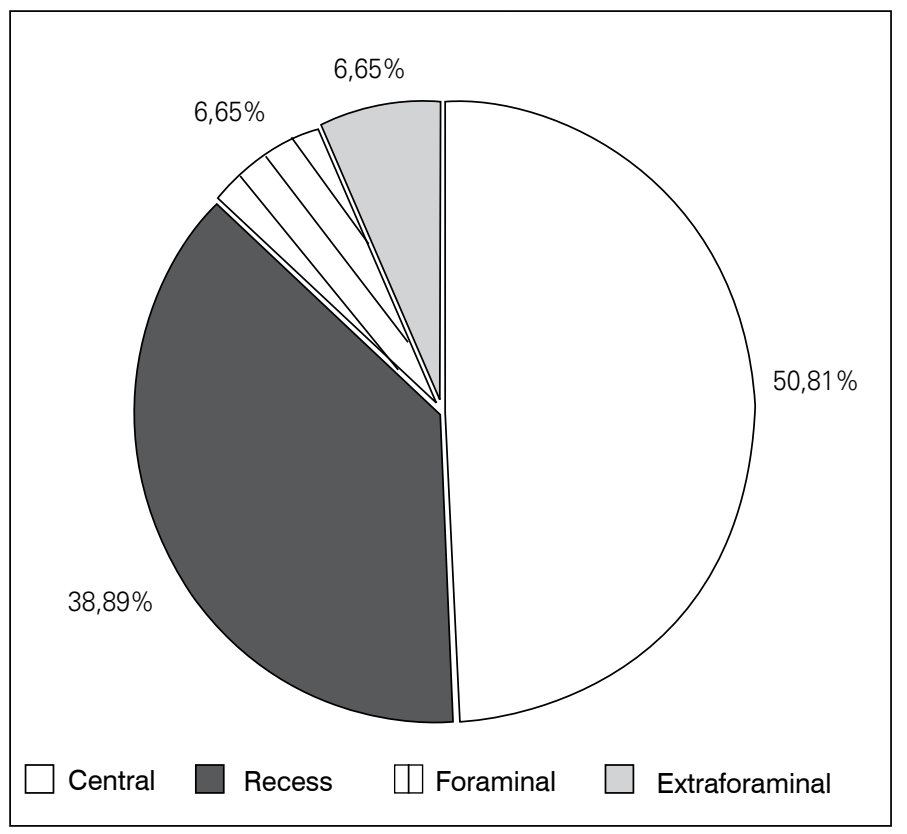

Figure 4. Distribution of axial location of herniated lumbar disc among the 61 patients from the study.

Table 2. Axial location of herniated lumbar disc in patients with low lumbar lordosis.

\begin{tabular}{c|c|c|c}
\hline $\begin{array}{c}\text { Location of the } \\
\text { herniated disc }\end{array}$ & Number & $\begin{array}{c}\text { Proportion } \\
\text { (\%) }\end{array}$ & p \\
\hline Recess & 4 & 13.8 & \multirow{2}{*}{0.000} \\
\hline Central & 24 & 82.8 & \\
\hline Extraforaminal & 1 & 3.4 & \\
\hline
\end{tabular}



Figure 5. Distribution of axial location of herniated lumbar disc in patients with low lumbar lordosis.

Of the 61 patients, 18 (29.5\%) presented with low sacral slope, 39 (63.9\%) normal, and four (6.6\%) high.

Among the 18 patients with low sacral slope, 15 (83.3\%) presented with central herniation and three (16.7\%) with recess herniation. The Binomial test proves that there is significant difference $(p<0.05)$ (Table 3 and Figure 6). 
Table 3. Axial location of herniated lumbar disc in patients with low sacral slope.

\begin{tabular}{c|c|c|c}
\hline $\begin{array}{c}\text { Location of the } \\
\text { herniated disc }\end{array}$ & Number & Proportion (\%) & p \\
\hline Central & 15 & 83.3 & \multirow{2}{*}{0.008} \\
\hline Recess & 3 & 16.7 & \\
\hline
\end{tabular}

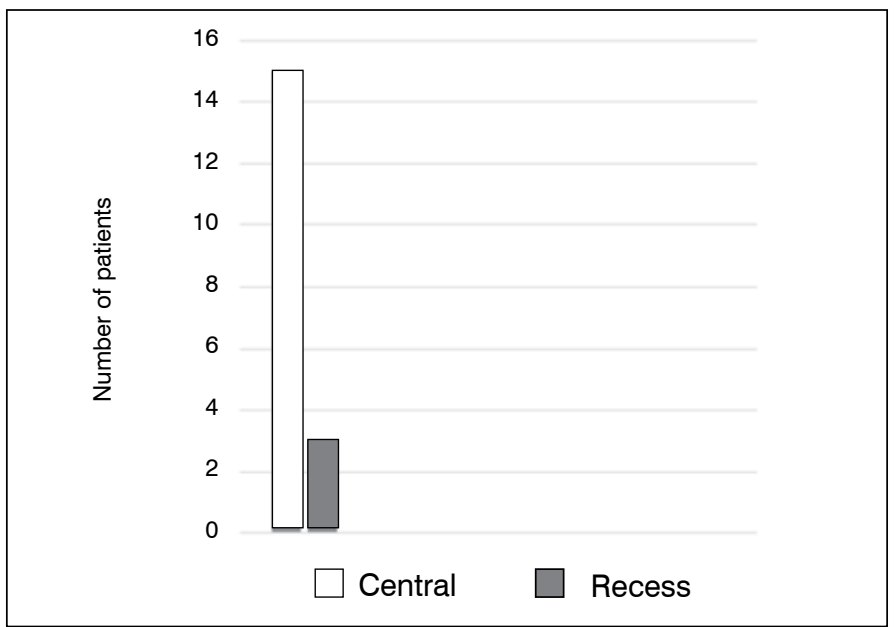

Figure 6. Distribution of the axial location of the herniated lumbar disc in patients with lower sacral slope.

Of the 61 patients, $23(37.7 \%)$ presented with low pelvic tilt, 22 (36.1\%) normal, and 16 (26.2\%) high.

Among the 22 patients with low pelvic tilt, eight (36.36\%) presented with central herniation; 12 (54.54\%) with recess herniation; one $(4.55 \%)$ with foraminal herniation; and one $(4.55 \%)$ with extraforaminal herniation; the results were statistically insignificant. (Table 4 and Figure 7)

Of the 61 patients, nine (14.8\%) presented with low pelvic incidence, 36 (59\%) with normal incidence and 16 (26.2\%) with high

Table 4. Axial location of the herniated lumbar disc in patients with low pelvic tilt.

\begin{tabular}{c|c|c|c}
\hline $\begin{array}{c}\text { Location of the } \\
\text { herniated disc }\end{array}$ & Number & Proportion (\%) & p \\
\hline Recess & 12 & 54.54 & \\
\cline { 1 - 2 } Central & 8 & 36.36 & \multirow{2}{*}{$\mathrm{p}>0.05$} \\
\cline { 1 - 2 } Foraminal & 1 & 4.55 & \\
\hline Extraforaminal & 1 & 4.55 & \\
\hline
\end{tabular}

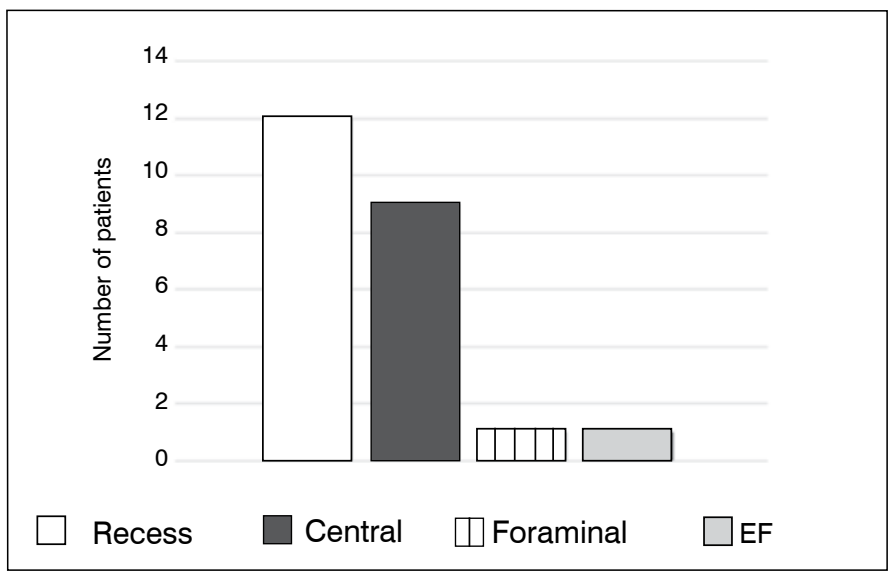

Figure 7. Distribution of the axial location of the herniated lumbar disc in patients with low pelvic tilt. incidence. The association of pelvic incidence with the axial location of the herniated lumbar disc was statistically insignificant.

The means of the sacral slope, pelvic tilt, pelvic incidence and lumbar lordosis parameters were compared for the central, recess, foraminal and extraforaminal disc herniations. There was statistical significance only for the comparison of lumbar lordosis (LL): central herniation $X$ foraminal herniation. Patients with mean central herniation of $34.8^{\circ}$ of $\mathrm{LL}$, foraminal herniation of $51.8^{\circ}$. Student's t-test $(p<0.05)$.

\section{DISCUSSION}

Roussouly and Pinheiro-Franco ${ }^{7}$ carried out a literature review. When the lumbar spine is hypolordotic and flat, the contact force acts mainly on the anterior column (vertebral bodies and discs) and its distribution favors the resultant force perpendicular to the discs, increasing the pressure on the disc. On the other hand, if lumbar lordosis is hypercurved, the force acts mainly on the posterior elements (joints, spinous processes).

Several studies have assessed sagittal balance in patients with degenerative diseases - herniated lumbar disc, lumbar discopathy and spondylolisthesis, and Roussouly et al. ${ }^{15}$ declared that patients with a low sacral slope $\left(<35^{\circ}\right)$ and slight pelvic tilt $\left(<45^{\circ}\right)$ have a tendency to forward displacement of forces and central herniated disc.

When the lumbar spine has increased lumbar lordosis, the Contact Force (CF) acts mainly on the posterior elements (joints, spinous processes). (Figure 8) On the other hand, if the lumbar spine is hypolordotic the CF acts mainly on the anterior column (vertebral bodies and discs), and its distribution favors the resulting force perpendicular to the discs, increasing the pressure on the disc. According to Roussouly, patients with structured hypolordosis (flatback syndrome) have a horizontalized disc and high disc pressure. These patients apparently have a high risk of developing central herniated disc. ${ }^{7,8,11,13,15}$

A study by Rajnics et al. ${ }^{13}$ affirmed that in patients with hypolordosis there is an increase in the compression force of gravity component. These increases in compression forces could speed up disc degeneration, corroborating our results.

In our study, of the 29 patients with low lumbar lordosis, 24 (82.8\%) presented with central herniated disc, with a statistical difference $(p=0.000)$. This association between low lordosis and central herniated disc is corroborated by the studies cited by Roussouly. ${ }^{7,8,11,13,15}$

In our study, of the 18 patients with low sacral slope, 15 (83.3\%) presented with central herniated disc, with statistical difference $(p=0.008)$. This association is corroborated by the studies of

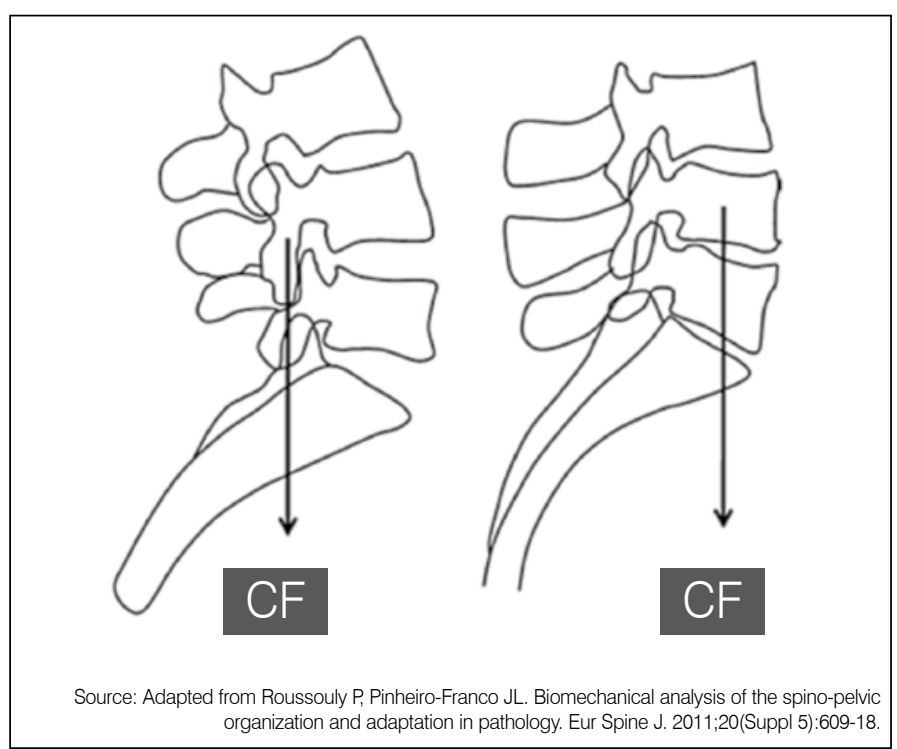

Figure 8. Contact force (CF) on posterior elements in hyperlodotic spine. Contact force (CF) on anterior elements in hypolordotic spine. 
Roussouly. $7,8,11,13,15$

Bolay et al. ${ }^{19}$ state that the ability to restore sagittal balance depends on pelvic incidence, sacral slope and pelvic tilt.

Roussouly affirm that there is a strong relationship between shape, position and function between pelvis and spine. Specific degenerative alterations can occur over time, depending on individual morphology. Sagittal parameters can be considered predictive in relation to the pelvis and spine. A better understanding of this relationship may lead to a better understanding of degenerative spinal diseases and better treatment strategy. $7,8,11,13,15$

\section{CONCLUSIONS}

There is a tendency for greater load distribution towards the anterior region of the spine when the spine is hypolordotic. This study observed an association between low lordosis and central herniated disc, as well as low sacral slope and central herniation.

All authors declare no potential conflict of interest concerning this article.

\section{REFERENCES}

1. Vialle LR, Vialle EM, Henao JE, Giraldo G. Hérnia discal lombar. Rev Bras Ortop. 2010;45(1):17-22.

2. Barros Filho TE, Basile Júnior $R$, Cristante $A F$, Araújo MP. Coluna toracolombar: síndromes dolorosas. In: Hebert S, Barros Filho TE, Xavier R, Pardini Júnior AG, editors. Ortopedia e traumatologia: princípios e prática. 4a ed. Porto Alegre: Artmed; 2009. p. 122-35.

3. Stienen MN, Cadosch D, Hildebrandt G, Gautschi OP. The lumbar disc herniation management, clinical aspects and current recommendations Praxis (Bern 1994). 2011;100(24):1475-85.

4. Deyo RA, Loeser JD, Bigos SJ. Herniated lumbar intervertebral disk. Ann Intern Med. 1990;112(8):598-603.

5. Barrey C, Jund J, Noseda O, Roussouly P. Sagittal balance of the pelvis-spine complex and lumbar degenerative diseases. A comparative study about 85 cases. Eur Spine J. 2007;16(9):1459-67.

6. Long DM, BenDebba M, Torgerson WS, Boyd RJ, Dawson EG, Hardy RW, et al. Persistent back pain and sciatica in the United States: patient characteristics. J Spinal Disord. 1996;9(1):40-58

7. Roussouly P, Pinheiro-Franco JL. Biomechanical analysis of the spino-pelvic organization and adaptation in pathology. Eur Spine J. 2011;20(Suppl 5):609-18.

8. Le Huec JC, Roussouly P. Sagittal spino-pelvic balance is a crucial analysis for normal and degenerative spine. Eur Spine J. 2011;20(Suppl 5):556-7.

9. Legaye J, Duval-Beaupère G, Hecquet J, Marty C. Pelvic incidence: a fundamental pelvic parameter for three-dimensional regulation of spinal sagittal curves. Eur Spine J. 1998;7(2):99-103.

10. Guigui $P$, Levassor N, Rillardon L, Wodecki P, Cardinne L. Physiological value of pelvic and spinal parameters of sagital balance: analysis of 250 healthy volunteers. Rev Chir Orthop Reparatrice Appar Mot. 2003;89(6):496-506.

11. Labelle H, Roussouly P, Berthonnaud E, Dimnet J, O'Brien M. The importance of spino- -pelvic balance in L5-s1 developmental spondylolisthesis: a review of pertinent radiologic measurements. Spine (Phila Pa 1976). 2005;30(Suppl 6):S27-34

12. Lee CS, Chung SS, Chung KH, Kim SR. Significance of pelvic incidence in the development of abnormal sagittal alignment. J Korean Orthop Assoc. 2006;41(2):274-80.

13. Rajnics P, Templier A, SkalliW, Lavaste F, Illes T. The importance of spinopelvic parameters in patients with lumbar disc lesions. Int Orthop. 2002;26(2):104-8.

14. Roussouly P, Berthonnaud E, Dimnet J. Geometrical and mechanical analysis of lumbar lordosis in an asymptomatic population: proposed classification. Rev Chir Orthop Reparatrice Appar Mot. 2003:89(7):632-9.

15. Mangione P, Sénégas J. [Sagittal balance of the spine]. Rev Chir Orthop Reparatrice Appar Mot. 1997;83(1):22-32.

16. Barrey C, Roussouly P, Perrin G, Le Huec JC. Sagittal balance disorders in severe degenerative spine. Can we identify the compensatory mechanisms? Eur Spine J. 2011;20(Suppl 5):626-33.

17. Vialle R, Levassor N, Rillardon L, Templier A, Skalli W, Guigui P. Radiographic analysis of the sagittal alignment and balance of the spine in asymptomatic subjects. J Bone Joint Surg Am. 2005;87(2):260-7.

18. Roussouly P, Gollogly S, Berthonnaud E, Dimnet J. Classification of the normal variation in the sagittal alignment of the human lumbar spine and pelvis in the standing position. Spine (Phila Pa 1976). 2005;30(3):346-53.

19. Boulay C, Tardieu C, Hecquet J, Benaim C, Mouilleseaux B, Marty C, et al. Sagittal alignment of spine and pelvis regulated by pelvic incidence: standard values and prediction of lordosis. Eur Spine J. 2006:15(4):415-22.

20. Fardon DF, Milette PC; Combined Task Forces of the North American Spine Society, American Society of Spine Radiology, and American Society of Neuroradiology. Nomenclature and classification of lumbar disc pathology. Recommendations of the Combined task Forces of the North American Spine Society, American Society of Spine Radiology, and American Society of Neuroradiology. Spine (Phila Pa 1976). 2001;26(5):E93-E113. 